Abstracta Iranica Abstracta Iranica

Revue bibliographique pour le domaine irano-aryen

Volume 24 | 2003

Comptes rendus des publications de 2001

\title{
Les Iraniens de Californie : si la République islamique n'existait pas... Paris, CERI, 2001, 41 p. (Les études du CERI, 75).
}

\section{Bernard Hourcade}

\section{(2) OpenEdition}

1 Journals

\section{Édition électronique}

URL : http://journals.openedition.org/abstractairanica/34894

DOI : 10.4000/abstractairanica.34894

ISSN : 1961-960X

Éditeur :

CNRS (UMR 7528 Mondes iraniens et indiens), Éditions de l'IFRI

\section{Édition imprimée}

Date de publication : 15 mai 2003

ISSN : 0240-8910

\section{Référence électronique}

Bernard Hourcade, «Les Iraniens de Californie : si la République islamique n’existait pas... Paris, CERI, 2001, 41 p. (Les études du CERI, 75). », Abstracta Iranica [En ligne], Volume 24 | 2003, document 323, mis en ligne le 05 janvier 2010, consulté le 25 septembre 2020. URL : http://journals.openedition.org/ abstractairanica/34894 ; DOI : https://doi.org/10.4000/abstractairanica.34894

Ce document a été généré automatiquement le 25 septembre 2020.

Tous droits réservés 


\section{Les Iraniens de Californie : si la} République islamique n'existait pas... Paris, CERI, 2001, 41 p. (Les études du CERI, 75).

\section{Bernard Hourcade}

1 Venant après l'études des Iraniens de Dubaï (Le retour de Sindbad, les Iraniens dans le Golf, Paris, CERI, 1999), cette analyse anthropologique de la communauté iranienne de Californie complète le panorama de cette nouvelle donnée du nationalisme iranien représentée par la diaspora iranienne, après les études de M. Bozorgmehr et G. Sabbagh. F.A. montre par le détail des situations vécues la vie quotidienne et la construction "conservatrice de l'iranité » par cette communauté qui a un rôle de leader et qui joue même un rôle dans la politique intérieure iranienne comme dans les relations irano-américaines. Il est dommage que cette étude très vivante et pertinente, fondée sur une longue enquête sur place, ne développe pas davantage la fonction politique et le rôle de lobby des Iraniens d' « Irangeles ».

\section{INDEX}

Thèmes : 13.1. Iran 
AUTEURS

BERNARD HOURCADE

CNRS - Paris 